uterine activity (Alexandria units) at varying doses of orciprenaline in seven patients studied for this effect is given in Table II. Tachyphylaxis was not observed in the three patients studied for 25,70 , and 90 minutes at orciprenaline doses of 18,20 , and $20 \mu \mathrm{g} / \mathrm{min}$. Uterine activity was reduced to less than $30 \mathrm{Alex}-$ andria units. The average steady state uterine activity before orciprenaline was 213 Alexandria units.

The orciprenaline effect on uterine contractility is clearly dose-dependent. Quiescent uterine activity, arbitrarily defined as activity of less than 30 Alexandria units, was achieved at doses of from 10 to $20 \mu \mathrm{g} / \mathrm{min}$, with a mean of $13.7 \mu \mathrm{g} / \mathrm{min}$. No difference in orciprenaline effect was observed in the patient contracting in response to prostaglandin $\mathrm{E}_{2}$. The significant effects on mother and fetus at the effective dose are shown in Table III.

\section{Discussion}

These results confirm that orciprenaline reduces uterine activity and show that this reduction is dose-dependent. Tachyphylaxis was not observed in the three patients studied specifically for this effect. This suggests that the previously recommended 20-minute periods of infusion (Baillie et al., 1970), though clinically convenient, could be extended. The effective dose varied from 10 to $20 \mu \mathrm{g} / \mathrm{min}$, with a mean of 13.6 $\mu \mathrm{g} / \mathrm{min}$. This dose was not related to the initial uterine activity, oxytocin dose, maternal or fetal weight, gestational age, or indication for induction. This effective dose differed markedly from the mean of $30 \mathrm{\mu g} / \mathrm{min}$ found effective in premature labour (Baillie et al., 1970). Possibly an excessive dose was administered in that study. Alternatively, premature labour on account of the progressive nature of the labour process (Friedman, 1967) may be less easily stopped. The "hormonal setting" of the myometrium may differ in the two circumstances (Pauerstein and Zauder, 1970).

The difference in effective dose in these two situations illustrates the difficulty in attempting to relate results from the study of one clinical situation to another which is apparently closely analagous. Even more fallacious is the attempt to relate to clinical work findings derived from either in-vitro human studies or any animal studies whether in vivo or in vitro. This lack of correlation is well established and reviewed (Pauerstein and Zauder, 1970; Pulkkinen, 1970).

Alexandria units were preferred to Montivedeo units as the duration of contraction is taken into account, thus giving a more accurate measure of uterine activity.

Maternal tachycardia and increase in pulse pressure were noted in all patients but presented no problems. The most unpleasant side effect was nausea and vomiting which occurred in three patients at the effective dose after 9,20 , and 22 minutes respectively. This may well limit the period of administration. Further clinical experience has shown that diazepam reduces this distressing symptom.

Some difficulty was encountered in recording the fetal heart rate phonocardiographically at higher infusion rates. This was due to the transmission of abdominal aortic sounds when the maternal pulse pressure was markedly increased. The maternal aortic sounds then obscured the fetal heart sounds so that the maternal pulse rate was recorded instead. In these circumstances the fetal heart rate was auscultated in the usual manner without difficulty.

We thank Professor J. A. Stallworthy for his advice and helpful criticism, and Mr. Arthur Williams, Mr. Edward Cope, and Mr. J. D. Ellis for permission to carry out this study on patients under their care. Our thanks are especially due to Miss Barker and the nursing staff at the Churchill Hospital for their outstanding cooperation. We are grateful to Dr. Patrick Knowlson for his advice and to Boehringer Ingelheim Limited for financial assistance.

\section{References}

Baillie, P., Meehan, F. P., and Tyack, A. J. (1970). British Medical fournal, 4,154

El-Sahwi, S., Gaafar, A. A., and Toppozada, H. K. (1967). American fournal of Obstetrics and Gynecology, 98, 900 .

Friedman, E. A. (1968). Labor: Clinical Evaluation and Management, p. 27. New York, Appleton-Century-Crofts.

Pauerstein, C. J., and Zauder, H. L. (1970). Obstetrical and Gynecological Survey, 25, p. 617

Pulkkinen, M. O. (1970). Acta Obstetricia et Gynecologica Scandinavica, 49, Supplement No. 1, p. 23.

\title{
Aplastic Anaemia, Acute Myeloblastic Leukaemia, and Oxymetholone
}

\author{
I. W. DELAMORE, C. G. GEARY
}

British Medical fournal, 1971, 2, 743-745

\section{Summary}

Four patients developed acute myeloblastic leukaemia after treatment of aplastic anaemia with oxymetholone. Two had previously shown an excellent clinical response to the drug and a third some improvement. Though no definite causal relationship between therapy and the onset of leukaemia has been established, the number of cases

University Department of Clinical Haematology, the Royal Infirmary, Manchester M13 9WL

I. W. DELAMORE, F.R.C.P.ED., M.R.C.PATH., Consultant Physician

C. G. GEARY, M.R.C.P.(ED., LOND.), M.R.C.PATH., Consultant Haematologist is greater than might have been expected by chance. The association of the two diseases is discussed.

\section{Introduction}

Acute leukaemia arising in patients thought to be suffering from aplastic anaemia has been reported on several occasions (Adams et al., 1951; Block et al. 1953; Mohler and Leavell, 1958; Wetherley-Mein, 1960), but it is a rare occurrence, and in the 102 cases of aplastic anaemia reported by Bernard and Najean (1965), the 60 reported by Lewis (1965), and the 45 reported by Israëls and Wilkinson (1961) none developed leukaemia. During the past 10 years only five such patients have been seen in the department of clinical haematology at Manchester Royal Infirmary and four of these occurred in the past 18 
months following the treatment of the original aplastic anaemia with oxymetholone.

\section{Patients and Methods}

The following four cases were referred to the university department of clinical haematology for investigation and treatment between October 1968 and October 1970. Haematological methods were those described by Dacie and Lewis (1968).

\section{Case 1}

An electrical engineer aged 63 presented in October 1969; there was a three-year history of excessive bruising after trauma. Examination showed no abnormal physical signs apart from anaemia and subconjunctival haemorrhages. The blood count was haemoglobin $9.5 \mathrm{~g} / 100 \mathrm{ml}$, white cells $1,900 / \mathrm{mm}^{3}$ (neutrophils $3 \%$, lymphocytes $95 \%$, eosinophils $2 \%$, platelets $38,000 / \mathrm{mm}^{3}$, reticulocytes $1 \%$. The marrow aspirate was severely hypoplastic, with reduction in all cell lines, but occasional cells were seen whose identity was uncertain; they might have been reticulum cells or atypical myeloblasts. Trephine biopsy showed severe hypoplasia. A diagnosis of hypoplastic anaemia was made but the possibility of an underlying leukaemia or reticulosis was recognised.

Treatment with prednisolone $30 \mathrm{mg}$ daily, shortly reduced to $10 \mathrm{mg}$ daily, and oxymetholone $150 \mathrm{mg}$ daily was begun. There was an undoubted response to this regimen though the granulocytopenia and thrombocytopenia persisted. On 1 April 1970 the blood count was $\mathrm{Hb} 12.6 \mathrm{~g} / 100 \mathrm{ml}$ white cells $2,400 / \mathrm{mm}^{3}$ (neutrophils $5 \%$, lymphocytes $94 \%$, myelocytes $1 \%$ ), platelets $67,000 / \mathrm{mm}^{3}$. At this visit oxymetholone was discontinued but small doses of betamethasone were maintained. By June his haemoglobin had fallen to $10.9 \mathrm{~g} / 100 \mathrm{ml}$ but his clinical condition remained good; on 29 July his blood count was $\mathrm{Hb} 8.7 \mathrm{~g} / 100 \mathrm{ml}$, white cells $2,000 / \mathrm{mm}^{3}$ (neutrophils $26 \%$, lymphocytes $69 \%$, monocytes $2 \%$, eosinophils $3 \%$ ), platelets $90,000 / \mathrm{mm}^{3}$, reticulocytes $3 \%$; the film showed some macrocytosis. Oxymetholone therapy was recommenced in a dosage of $150 \mathrm{mg}$ daily, increased to $250 \mathrm{mg}$ daily on 26 August. There was a rise in the platelet count to $120,000 / \mathrm{mm}^{3}$, but he remained anaemic and transfusion was necessary. His clinical condition deteriorated and sweating became troublesome.

A marrow aspiration on 3 September showed a moderately cellular specimen but with increased numbers of blasts presumed to be myeloblasts. Cytochemical stains were unhelpful. Further marrow aspirates in October were of variable cellularity but showed a more definitely leukaemia picture. There were still no leukaemic features in the blood but a diagnosis of subleukaemic myeloblastic leukaemia was made and a small dose of cytosine arabinoside given. His clinical condition deteriorated further with the development of Escherichia coli septicaemia. He died one year after the original diagnosis of aplastic anaemia.

\section{Case 2}

A 65-year-old housewife gave a history of hysterectomy for carcinoma of the uterus (1963) followed by cyclophosphamide therapy for two years. During this period no haematological abnormality was detected. In 1966 she developed thyrotoxicosis and was treated with radioactive ${ }^{131} \mathrm{I}$; she became euthyroid and later hypothyroid. In October 1968 she attended the haematology department with a two-month history suggestive of anaemia; physical examination showed no abnormality apart from anaemia.

On 23 October the blood count was $\mathrm{Hb} 6.8 \mathrm{~g} / 100 \mathrm{ml}$ white cells $3,750 / \mathrm{mm}^{3}$ (neutrophils $48 \%$, lymphocytes $47 \%$, monocytes $3 \%$, plasma cells $1 \%$, eosinophils $1 \%$ ), platelets $67,000 / \mathrm{mm}^{3}$, reticulocytes $<1 \%$. Occasional nucleated red cells were noted in the film. Two marrow aspirates showed hypoplasia with a relative sparing of megakaryocytes. Two attempts at trephine biopsy were unsuccessful. Ham's test was negative. She was transfused and treatment was begun with prednisolone $25 \mathrm{mg}$ daily and thyroxine $0.1 \mathrm{mg}$ daily. There was little change on this regimen and a further transfusion was necessary. On 6 February the blood count was $\mathrm{Hb}$ $8.9 \mathrm{~g} / 100 \mathrm{ml}$, white cells $3,850 / \mathrm{mm}^{3}$ (neutrophils $57 \%$, lympho- cytes $33 \%$, monocytes $6 \%$, eosinophils $3 \%$, basophils $1 \%$ ), platelets $86,000 / \mathrm{mm}^{3}$. Oxymetholone $100 \mathrm{mg}$ thrice daily was begun on this visit and on 28 February the blood count was $\mathrm{Hb} 9.5 \mathrm{~g} / 100 \mathrm{ml}$, white cells $8,800 / \mathrm{mm}^{3}$ (neutrophils $85 \%$, lymphocytes $11 \%$, monocytes $3 \%$, eosinophils $1 \%$ ), platelets $76,000 / \mathrm{mm}^{3}$, reticulocytes $8 \%$.

A gradual response to oxymetholone continued and on 28 August the blood count was $\mathrm{Hb} 12 \cdot 1 \mathrm{~g} / 100 \mathrm{ml}$, white cells $3,200 /$ $\mathrm{mm}^{3}$ (neutrophils $72 \%$, lymphocytes $25 \%$, monocytes $3 \%$ ) platelets $92,000 / \mathrm{mm}^{3}$. On 25 September she was admitted to hospital with symptoms of large-bowel obstruction. Surgery was performed on 23 October, when a colonic stricture due to diverticulitis was removed. Several blood transfusions were given at the time of operation; on discharge (10 December) the haemoglobin was $8.0 \mathrm{~g} /$ $100 \mathrm{ml}$. Treatment with oxymetholone, prednisolone, and thyroxine was continued but there was no sustained response. Further transfusions were necessary, and in March 1970 primitive cells appeared in the blood. On 31 March the blood count was Hb $8.3 \mathrm{~g} /$ $100 \mathrm{ml}$, white cells $40,600 / \mathrm{mm}^{3}$ (myeloblasts $94 \%$ ), nucleated red cells $10 / 200$ white cells, platelets $12,000 / \mu 1$. The patient's condition deteriorated and she died on 9 April 1970. Necropsy confirmed the diagnosis of acute myeloblastic leukaemia.

\section{Case 3}

A 44-year-old labourer first presented in October 1969 with a three-month history of anaemia requiring weekly transfusions. There was no history of exposure to marrow toxins and there were no physical signs apart from anaemia. The blood count was $\mathrm{Hb}$ $4.7 \mathrm{~g} / 100 \mathrm{ml}$, white cells $1,800 / \mathrm{mm}^{3}$ (polymorphs $14 \%$, lymphocytes $37 \%$, monocytes $46 \%$, eosinophils $2 \%$, promyelocytes $1 \%$ ), leucocyte alkaline phosphatase score 202 (normal range 15-100), platelets $42,000 / \mathrm{mm}^{3}$. Occasional nucleated red cells were noted in the film. Bone marrow aspiration showed severe hypoplasia with a relative increase in reticulum, lymphoid, and plasma cells. Megakaryocytes were moderately numerous. Trephine biopsy confirmed marrow hypoplasia.

On 15 October treatment with oxymetholone $(250 \mathrm{mg} /$ day $)$ and prednisolone $(50 \mathrm{mg} / \mathrm{day})$ was begun and he received several blood transfusions. There was gradual but undoubted improvement in his clinical condition and the blood count on 9 February 1970 was $\mathrm{Hb} 8.3 \mathrm{~g} / 100 \mathrm{ml}$, white cells $4,550 / \mathrm{mm}^{3}$ (neutrophils $38 \%$, lymphocytes $26 \%$, monocytes $16 \%$, eosinophils $2 \%$, metamyelocytes $10 \%$, blasts $8 \%$ ), platelets $99,000 / \mathrm{mm}^{3}$, reticulocytes $2 \%$. The onset of cholestatic jaundice at this stage necessitated reduction of the dose of oxymetholone to $150 \mathrm{mg}$; a small dose of prednisolone was continued. No further transfusions were necessary until 20 April when there was a sudden deterioration in his condition associated with large numbers of blasts in the blood. On 20 April the $\mathrm{Hb}$ was $5.1 \mathrm{~g} / 100 \mathrm{ml}$, packed cell volume $16 \%$, white cells $23,000 / \mathrm{mm}^{3}$ (neutrophils $14 \%$, lymphocytes $12 \%$, monocytes $6 \%$, eosinophils $1 \%$, blasts $67 \%$ ), platelets $162,000 /$ $\mathrm{mm}^{3}$, reticulocytes $<1 \%$. The bone marrow aspirate was abundantly cellular, the predominant cell being a vacuolated blast which was para-aminosalicylic acid and peroxidase negative. Megakaryocytes were abundant. It seemed that the diagnosis was now unequivocally acute myeloblastic leukaemia.

Treatment with cytosine arabinoside was begun; there was an abrupt fall in his white cell count, and further transfusions were necessary. A marrow aspiration on 6 May again showed hypoplasia, and this was confirmed by trephine biopsy. There was then a gradual clinical improvement, but blast cells persisted in the blood and the spleen tip became palpable. Mercaptopurine $(150 \mathrm{mg}$ daily) was begun on 11 June. On 6 August the blood count was Hb 9.0 g/ $100 \mathrm{ml}$, white cells $2,000 / \mathrm{mm}^{3}$ (neutrophils $8 \%$, lymphocytes $89 \%$, monocytes $2 \%$, blasts $1 \%$ ), platelets $37,000 / \mathrm{mm}^{3}$. Marrow aspiration again showed a hypoplastic picture and another course of oxymetholone was given. Blood transfusions were still necessary, and his white cell count rose once more. Another short course of cytosine was given in September. His condition then gradually deteriorated and there was mo evidence of definite remission in the leukaemia though his blast cell count fell after cytosine. A recent blood count showed $\mathrm{Hb} 7 \cdot 3 \mathrm{~g} / 100 \mathrm{ml}$, white cells $58,000 /$ $\mathrm{mm}^{3}$ (neutrophils $4 \%$, lymphocytes $2 \%$, myelocytes $1 \%$, blasts $93 \%$ ), platelets $26,000 / \mathrm{mm}^{3}$, leucocyte alkaline phosphatase score 2 . His condition gradually deteriorated and he died 18 months after the original diagnosis of aplastic anaemia. Necropsy confirmed the final diagnosis of acute myeloblastic leukaemia. 


\section{Case 4}

A 65-year-old businessman was admitted under the care of $\mathrm{Mr}$. Thomas Moore. He was complaining of urinary retention and developed haematuria after catheterization. He gave a history of pallor and tiredness for four to five months. He had received frequent courses of sulphamethizole (Urolucosil) over several years for a recurrent urinary infection. There were no physical signs apart from anaemia. At diagnosis the blood count was $\mathrm{Hb} 8.1 \mathrm{~g} / 100 \mathrm{ml}$, white cells $2,500 / \mathrm{mm}^{3}$ (neutrophils $3 \%$, lymphocytes $95 \%$, myelocytes $2 \%$ ), reticulocytes $1 \%$, leucocyte alkaline phosphatase score 180 . Ham's test was negative. The blood film appeared slightly macrocytic. The marrow aspirate was severely hypoplastic and showed a relative increase in lymphoid and reticulum cells but no increase in primitive cells. Two trephine biopsies confirmed a diagnosis of aplastic anaemia.

Treatment with oxymetholone was begun on 10 September 1970 but there was no definite response; his haemoglobin remained around $8 \mathrm{~g} / 100 \mathrm{ml}$ until 5 October, when it fell after urinary tract haemorrhage; further transfusions were required. On 9 October the blood count was $\mathrm{Hb} 7.4 \mathrm{~g} / 100 \mathrm{ml}$, white cells $2,700 / \mathrm{mm}^{3}$ (neutrophiles $10 \%$, lymphocytes $73 \%$, monocytes $2 \%$, eosinophils $11 \%$, blasts $4 \%$ ), platelets $28,000 / \mathrm{mm}^{3}$. The marrow was moderately cellular, most of the cells having the appearance of myeloblasts or erythroblasts, with a smaller number of lymphocytes; megakaryocytes were poorly represented. It was considered that this picture, though suggestive of acute leukaemia, might possibly represent a 'recovery' phase in aplastic anaemia; but there was no evidence of regeneration in the blood, and after three days a 72hour infusion of cytosine arabinoside in a dosage of $200 \mathrm{mg} /$ day was given. There was a fall in his white cell and platelet counts, and further transfusions were necessary.

A marrow aspiration on 20 October confirmed the diagnosis of acute myeloblastic leukaemia. During the next month his clinical condition remained extremely poor, with thrombocytopenic haemorrhage and septicaemia. He was treated with antibiotics; oxymetholone therapy was discontinued when jaundice appeared. There was then a gradual improvement, haemorrhage ceased, and blast cells disappeared from the blood. However, a myelogram on a specimen obtained on 1 December still showed $14 \%$ myeloblasts. His latest blood count (28 January 1971) was $\mathrm{Hb} 9 \cdot 8 \mathrm{~g} / 100 \mathrm{ml}$, white cells $2,200 / \mathrm{mm}^{3}$ (neutrophiles $13 \%$, lymphocytes $82 \%$, monocytes $2 \%$, eosinophils $1 \%$, basophils $1 \%$, myelocytes $1 \%$ ), platelets $10,000 / \mathrm{mm}^{3}$, leucocyte alkaline phosphatase score 279 cells. The marrow aspirate was again compatible with acute myeloblastic leukaemia.

\section{Discussion}

All four patients had received treatment with the anabolic steroid oxymetholone (s-hydroxymethylene-17 $\alpha$-methyl dihydrotestosterone). The mode of action of this drug is uncertain (Silink and Firkin, 1968) but it has been shown to produce remission in about $50 \%$ of patients suffering from aplastic anaemia (Sanchez Medal et al., 1964). It may act as an erythropoietin synergist rendering the primitive stem cell sensitive to the hormone and therefore stimulating differentiation into red cell precursors. Alternatively it may increase the mitotic rate of the stem cell or colony forming unit; there is some evidence for this in the increased erythroblast mitotic index and the increase in the overall mitotic index of primary blood cells (Byron, 1970).

All four patients were originally diagnosed as suffering from aplastic anaemia but eventually developed acute leukaemia after treatment with oxymetholone. In only one of these patients (Case 4) was there a history of drug ingestion which might have been responsible for the disease. It is occasionally very difficult to differentiate aplastic anaemia from early acute myeloblastic leukaemia in subleukaemic phase, with a hypoplastic marrow; as long ago as 1943 Davidson et al., drew attention to the presence of small primitive cells resembling myeloblasts in the bone marrow aspirates of some patients with aplastic anaemia. These cells he called " $Q$ " cells. Two of our patients (Cases 1 and 3) fell into this category, but on the basis of bone marrow trephine biopsy and the overall clinical and haematological picture a diagnosis of aplastic anaemia was made before treatment, and indeed some response to oxymetholone was shown.

To explain this sequence of events the following possibilities are proposed. (1) The patients had acute leukaemia from the onset but presented with a hypoplastic bone marrow and proceeded to frank leukaemia. In this case the possibilities are that oxymetholone $(a)$ was not implicated, $(b)$ accelerated the appearance of frank leukaemia, or (c) produced clinical improvement and thus allowed the patient to live long enough for the true nature of the disease to declare itself. (2) The patients had true aplastic anaemia with subsequent development of acute leukaemia either as a result of oxymetholone therapy or spontaneously.

When considering these possibilities it is of interest to note three things. The first is that there was an apparent haematological response to oxymetholone therapy in three of the four cases, and if this drug acts by stimulating the primitive stem cell it might be expected to accelerate the appearance of abnormal cells in bone marrow or blood when the stem cell itself is abnormal. This would not exclude the possibility that some derivatives of such an abnormal stem cell might still be capable of differentiating into erythroblasts and megakaryocytes and thus cause temporary haematological and clinical remission.

Secondly, there are several other clinical situations in which aplastic anaemia and acute myeloblastic leukaemia may be associated. There is a known association between the Fanconi type of congenital aplastic anaemia and acute leukaemia; a similar association exists in paroxysmal nocturnal haemoglobinuria, in which a variable degree of marrow hypoplasia occurs, and may be followed by acute leukaemia. Substances such as butazolidine and benzene which undoubtedly cause aplasia have been reported to be leukaemogenic; acute myeloblastic leukaemia has been reported to follow aplastic anaemia due to chloramphenicol (Cohen and Cregar, 1967) but in this instance the patient had received fluoxymesterone after the onset of aplasia.

Thirdly, there is a distinction to be drawn between preleukaemic and potentially leukaemic conditions. WetherleyMein (1960) regarded aplastic anaemia progressing to acute leukaemia as "preleukaemic," but Roberts et al. (1968) suggested that some cases may be only "potentially" leukaemic; if this is so then oxymetholone might be regarded as increasing this potentiality.

We would, however, point out that the case against the drug is far from proved; it certainly produced a worthwhile clinical remission in two patients who might otherwise have succumbed to their aplastic anaemia. It is hoped that this paper will encourage others to report their experience with the use of oxymetholone so that a more complete picture may emerge.

\section{References}

Adams, E. B. (1951). Lancet, 1, 657.

Bernard, J., and Najean, Y. (1965). Series Haematologica, 5, 1.

Byron, J. W. (1970). Nature, 228, 1204

Block, M., Jacobson, L. O., and Bethard, W. F. (1953). fournal of the American Medical Association, 152, 1018.

Cohen, T., and Cregar, W. P. (1967). American fournal of Medicine, 43, 762.

Dacie, J." V., and Lewis, S. M. (1968). Practical Haematology, 4th ed. London, Churchill.

Davidson, L. S. P., Davis, L. J., and Innes, J. (1943). Edinburgh Medical fournal, 50, 226

Israêls, M. C. G., and Wilkinson, J. F. (1961). Lancet, 1, 63.

Lewis, S. M. (1965). British Medical fournal, 1, 1027

Mohler, D. N., and Leavell, B. S. (1958). Annals of Internal Medicine, 49,

Roberts, B. E., Abbott, C. R., Fortt, R. W., and Pyrah, R. D. (1968). Acta Haematologica, 39, 20.

Sanchez Medal, L., Pizzuto, J., Torre-Lopez, E., and Derbez, R. (1964). Archives of Internal Medicine, 113, 721 .

Silink, S. J., and Firkin, B. G. (1968). Australian Annals of Medicine, 17, 224.

Wetherley-Mein, G. (1960). In Lectures on Haematology, ed. F. G. J. Hayhoe, p. 132. London, Cambridge University Press. 